\title{
TRIPS drug amendment a start
}

Cite as: CMAJ 2017 February 21;189:E289. doi: 10.1503/cmaj.1095391

$\mathrm{n}$ a development termed "extremely important" by

World Trade Organization (WTO) Director-General Roberto Azevêdo, many poor- and middle-income countries may at last be able to import cheap generic drugs for high-mortality diseases such as HIV/AIDS, tuberculosis, malaria and pneumonia.

It's been a long road. An amendment to the WTO's Trade Related Aspects of Intellectual Property Rights (TRIPS) regime was first proposed in 2003. On Jan. 23, 2017, the required two-thirds of the WTO's 164 member-countries finally agreed to adopt the amendment which allows drug-deprived countries to request WTO "waivers" so they can import very cheap generic drugs.

Previously under TRIPS, the governments of poor and developing countries could get "compulsory licenses" to produce inexpensive generic medicines for their domestic markets without the patent owners' consent. But TRIPS blocked them from exporting to other needy nations. This meant that countries without manufacturing capacity couldn't access cheap generic drugs from nations with compulsory licenses.

"[The amendment] gives legal certainty that generic medicines can be exported at reasonable prices to satisfy the needs of countries with no pharmaceutical production capacity, or those with limited capacity," Azevêdo said in a videotaped statement.

But some point to failed Canadian leg- islation as evidence that more than the amendment is required. Canada's 2004 legislation (The Jean Chrétien Pledge to Africa) followed much the same process as Azevêdo now describes as a breakthrough. But 13 years after Canada's law was passed, only one shipment of generics from Canada has been exported to a needy nation.

An international analyst says the amendment alone will have a "very limited" impact without further action from the WTO. Dr. Rohit Malpany, director of policy and analysis for Médecins Sans Frontières (MSF) in Paris says the WTO needs to simplify the waiver application process, provide legal support to appli- cant nations, support the development of unpatented low-cost new drugs, and force pharmaceutical companies to become much more transparent about their price-setting decisions.

Canada could also have a role, says Richard Elliott, executive director of the Canadian HIV/AIDs Network in Toronto, who says he's committed to the idea that Canada could use the WTO's waiver process to help needy nations. "If we are ever going to get this to work, the Liberal government will have to get behind this again in a very forceful, and far more effective way."

Paul Webster, Toronto, Ontario 